\title{
Blood platelets and blood clotting.
}

By T. F. Z UCKER (by invitation).

[From the H. K. Cushing Laboratory of Experimental Medicine, Western Reserve University, Cleveland, Ohio.]

That the formed elements of the blood play a part in normal coagulation has long been known. Both leucocytes and platelets have been said to yield substances which contribute to fibrin formation. Leucocytes alone, however, will not coagulate fibrinogen. Cramer and Pringle ${ }^{1}$ have recently shown that oxalate plasma freed from platelets by filtering through clay filters does not clot on adding an amount of $\mathrm{CaCl}_{2}$ which causes a similar centrifuged but unfiltered plasma to clot in a short time. That platelets disintegrate during coagulation, and that the addition of oxalate preserved them is well known. As early as I88I Fano² appreciated the fact that centrifuging was not sufficient to remove all cellular elements, and therefore resorted to filtration through a clay filter.

Regarding the effect of other anticoagulants, it has been observed by Buerker ${ }^{3}$ and by Deetjen ${ }^{4}$ that the breaking down of platelets in shed blood as observed under the microscope was inhibited by all those substances which can be used in preventing coagulation. They mention oxalates, citrates, $\mathrm{NaPO}, \mathrm{Na}_{2} \mathrm{HPO}_{43}$, salts of $\mathrm{Mn}, \mathrm{Fe}$ and $\mathrm{Ni}, \mathrm{MgSO}_{4}, \mathrm{Na}_{2} \mathrm{CO}_{3}$, peroxides and hirudin. The fact that these substances all have platelet preservative properties, does not necessarily mean that their anticoagulant effect is due solely to the fact that platelets remain intact.

The experiments of Cramer and Pringle seem to show that oxalate is an anticoagulant because it preserves platelets. That this is more generally the mode of action of anticoagulants is shown by the following data. Citrate plasma gives exactly the same results as oxalate plasma, which has also been verified by

${ }^{1}$ Quart. Journ. Exp. Physiol., 6, I (1913).

2 Arch. f. Physiol., 1881, p. 277.

'Buerker, Pflug. Arch., 102, 36 (1904).

- Deetjen, Zts. physiol. Chem., 63, I (1909). 
others. Of greater interest than citrate are the anticoagulants which do not affect calcium. A plasma was obtained by drawing blood into an equal volume of a I per cent. solution of $\mathrm{MnCl}_{2}$ in 0.9 per cent. $\mathrm{NaCl}$. If this is treated with enough $\mathrm{Na}_{2} \mathrm{HPO}_{4}$ to precipitate the manganese, it coagulates quite readily. On centrifuging this plasma at a moderate speed to remove red cells and leucocytes (this also throws down some platelets), the coagulation is slightly deferred. By filtering through a clay filter a plasma is obtained which is not coagulated at all by $\mathrm{Na}_{2} \mathrm{HPO}_{4}$. Further evidence is furnished by making use of the fact that platelets on disintegrating yield a vasoconstrictor material. ${ }^{1}$ The manganese chloride plasma when tested on artery rings gives no constriction, but on addition of $\mathrm{Na}_{2} \mathrm{HPO}_{4}$ it clots and gives marked constriction. This is the same result obtained with citrate and $\mathrm{CaCl}_{2}$, and indicates clearly that the change taking place on adding $\mathrm{Na}_{2} \mathrm{HPO}_{4}$ is disintegration of platelets.

The observation of Buerker that $\mathrm{MgSO}_{4}$ preserves platelets I have verified by centrifuging a magnesium sulphate plasma fractionally and staining the sediment with Wright's stain. The same was observed with $\mathrm{NaCl}$ and $\mathrm{Na}_{2} \mathrm{SO}_{4}$. It is, however, much more difficult to separate platelets from plasmas containing high concentration of salts $\left(\mathrm{NaCl}, \mathrm{MgSO}_{4}, \mathrm{Na}_{2} \mathrm{SO}_{4}\right)$ than with oxala te citrate or fluoride, one reason being that on centrifuging the leucocytes and platelets do not form a well-marked zone, but largely sink into the red cell layer.

If a fresh salted plasma (I have used $\mathrm{MgSO}_{4}$ and $\mathrm{NaCl}$ ) is thoroughly centrifuged to remove the platelets as far as possible, this plasma when compared with the cell containing residue after dilution of both with normal saline, shows a much greater clotting time, or does not clot at all. The high concentration of salts does not permit the use of the test for vasoconstrictor material.

Hirudin also as tested by Buerker's or Deetjen's method preserves platelets. O'Connor ${ }^{2}$ and others have found that hirudin prevents the liberation of vasoconstrictor material in shed blood. This indicates that hirudin prevents coagulation not only by an antithrombin action, but also by preserving platelets. Which of

1 Zucker and Stewart, Zenir. f. Physiol., 27, 85 (1913).

2 Arch. f. Exp. Path. and Pharmakol., 67, 195 (1912). 
these plays the more important rôle in keeping blood in a fluid state cannot as yet be definitely decided. It seems to follow from the results stated above that if hirudin is used in sufficient quantity to prevent platelet disintegration entirely, the antithrombin action will not come into play at all.

Concerning the physico-chemical mechanism of platelet disintegration, we can as yet say nothing definite. Ca ions seem to be essential, and on that basis the effect of calcium precipitants (oxalates and fluorides) can be explained. Whether citrate decreases the ionization of $\mathrm{Ca}$ sufficiently to make the remaining $\mathrm{Ca}$ ions negligible has, I believe, never been determined quantitatively. Mn salts do not affect the calcium, but act directly on the platelets, and the possibility suggests itself that the action of citrates may be of the same kind. Gessard ${ }^{1}$ reports data which show an antagonism between $\mathrm{Ca}$ and $\mathrm{Mn}$ ions, $i . e$. , within certain limits additional calcium may overcome the anticoagulant effect of $\mathrm{Mn}$. Regarding the mode of action of hirudin and salts used in "salted plasmas," nothing at all can be said.

To decide the question whether the platelet preservatives antagonize the disturbing action of calcium on colloidal equilibrium of the lipoids of the cell membrane (i.e., surface layer) as recently suggested by Clowes ${ }^{2}$ and West for citrate, would require further experiments.

The suggestion of Buerker that clotting is the immediate consequence of platelet disintegration acquires new interest in the light of the experiments with clay filters. It will be noticed that the material to which the name prothrombin has been given closely coiresponds in properties to intact platelets. In that case thrombin would be equivalent to disintegrated platelets; thrombokinase would be any substance $\left(\mathrm{CaCl}_{2}\right.$, tissue juices) which accelerates the disintegration of platelets.

From the above data, it appears clearly that the condition of platelets is of the greatest importance in coagulation. We cannot say that preserving the platelets intact is the only means of keeping blood in a fluid condition, but it does seem that in every case where blood remains uncoagulated, the platelets are

${ }^{1}$ Compt. Rend., I53, I24I (I9II).

2 Proc. Soc. EXr. Biol. ANd Med., XI, 6, 1913. 
involved in some way. Experiments now in progress on the part which platelets play in the formation of peptone plasma are reserved for a separate communication. It may be stated here that after injection of peptone into a dog, the platelets are not destroyed (a statement often met with), although they disappear from circulating blood, and that in the blood there appears a substance similar in its actions to hirudin, which preserves platelets and prevents formation of fibrin (antithrombin).

\section{7 (854)}

The output of fecal bacteria as influenced by fasting and by high and low protein ingestion.

By N. R. Blather wick and P. B. Hawk.

[From the Laboratories of Physiological Chemistry of Jefferson

Medical College and the University of Illinois.]

By means of a seven-day fast the daily excretion of fecal bacterial nitrogen by a 76-kilogram man (E) was reduced from I.57I gram to 0.IoI gram, whereas the actual weight of the excreted bacterial substance was reduced from 14.336 grams to 0.920 gram per day. The percentage of the fecal nitrogen which was present as bacterial nitrogen was decreased from 55.82 per cent. to 32.39 per cent. as a result of the fast. The percentage of dry bacteria in dry feces was slightly increased.

The output of bacterial nitrogen and the output of bacterial substance were approximately the same on a low protein diet as during fasting. With the ingestion of a high protein diet these values underwent an immediate pronounced increase.

The percentage of the fecal nitrogen which was composed of bacterial nitrogen was about the same in the periods of low and high protein ingestion.

There was no definite relationship between the excretion of fecal bacteria and that of urinary indican.

The ingestion of 5.23 grams of nitrogen after the fast was followed by an excretion of fecal bacteria which was only $1 / 14$ as great as when four times that amount of nitrogen was ingested before the fast. 